\title{
PENGEMBANGAN MEDIA PEMBELAJARAN VIDEO PADA MATA KULIAH BAHASA INGGRIS DI ERA NEW NORMAL
}

\author{
Adelina Anum ${ }^{1}$, Novalia ${ }^{2}$ \\ ${ }^{(1)}$ Universitas Sang Bumi Ruwa Jurai \\ (2) Universitas Sang Bumi Ruwa Jurai \\ punya.adel@gmail.com ${ }^{1}$,novaliasholehah@gmail.com ${ }^{2}$
}

\begin{abstract}
Abstrak
Tujuan dari penelitian ini adalah untuk mengembangkan media pembelajaran video pada mata kuliah bahassa inggris di era new normal dan mengetahui kelayakan media pembelajaran video pada mata kuliah bahassa inggris di era new normal. Desain penelitian yang digunakan dalam penelitian ini adalah penelitian dan pengembangan (research and development. Model pengembangan ini terdiri dari lima tahapan yaitu analisis (analysis), desain (design), pengembangan (development), implementasi (implementation) dan evaluasi (evaluation). Penelitian ini dilakukan di Universitas Sang Bumi Ruwa Jurai dengan subjek penelitian yaitu mahasiswa Fakultas Hukum Semester satu. Hasil dari penelitian pengembangan ini berupa produk video pembelajaran yang telag diuji kelayakannya oleh ahli media, ahli materi, peer review dan mahasiswa sebagai pengguna media tersebut. Keseluruhan hasil uji coba menunjukkan bahwa media pembelajaran ini sangat layak digunakan dalam proses pembelajaran Bahasa Inggris di era new normal. Rincian dari masing-masing hasil uji coba adalah a) uji ahli materi mendapatkan hasil rerata sebesar $90 \%$ yaitu masuk dalam kategori sangat layak, b) uji ahli media mendapatkan hasil rerata 90\% yaitu masuk dalam kategori sangat layak, c) uji peer review mendapatkan hasil rerata 88\% dengan kategori sangat layak dan uji mahasiswa mendapatkan hasil $85 \%$ yang termasuk dalam kategori sangat layak. Berdasarkan hasil uji kelayakan media pembelajaran tersebut dapat disimpulkan bahwa video pembelajaran layak untuk digunakan sebagai media pembelajaran pada mata kuliah Bahasa Inggris di era new normal.
\end{abstract}

Kata Kunci: media pembelajaran, video, bahasa inggris

\begin{abstract}
The purpose of this research is to develop video learning media in English language courses in the new normal era and to find out the feasibility of video learning media in English language courses in the new normal era. The research design used in this study is research and development. This development model consists of five stages, namely analysis, design, development, implementation and evaluation. This was conducted at Sang Bumi Ruwa Jurai University with the research subject, namely students of the First Semester Faculty of Law. The results of this development research were in the form of learning video products that had been tested for feasibility by media experts, material experts, peer reviews and students as users of the media. try to show that this learning media is very suitable for use in the English learning process in the new normal era. The details of each trial result are a) the material expert test gets an average result of $90 \%$, which is in the very feasible category, b) the expert test media get an average result of $90 \%$, which is included in the very rich category $\mathrm{k}, \mathrm{c}$ ) the peer review test got an average result of $88 \%$ in the very feasible category and the student test got a result of $85 \%$ which was included in the very feasible category. Based on the results of the feasibility test of the learning media, it can be concluded that the instructional video is feasible to be used as a learning medium in English courses in the new normal era.
\end{abstract}

Keywords: learning media, video, English

\section{PENDAHULUAN}

Pada tahun 2020 terjadi beberapa transisi yang membawa dampak baik dan buruk dalam beberapa sektor, terutama dalam sektor pendidikan. Penyebab dari adanya hal ini adalah menyeruaknya kasus Corona Virus Disease 2019 (Covid-19) yang mulai masuk ke Indonesia sejak awal tahun. Adanya pandemi Covid-19 membawa dampak bagi proses 
belajar dan pembelajaran baik di tingkat, TK, SD, SMP, SMA maupun Perguruan Tinggi. Masa-masa ini mengharuskan adanya perubahan seperti bekerja, belajar dan bekerja dari rumah. Memasuki era new normal, beberapa kegiatan seperti bekerja dan beribadah sudah bisa dilakukan diluar rumah. Sedangkan untuk belajar dalam pelaksanaannya masih dilakukan dari rumah masing-masing. Adapun yang menerapkan pembelajaran di kelas hanya berlaku di beberapa kampus dan wajib menikuti protokol kesehatan.

Adanya pembelajaran daring di era new normal ini menuntut dosen untuk dapat merancang pembelajaran dengan menggunakan berbagai media belajar yang berbasis Teknologi Informasi yang sesuai dengan kebutuhan mahasiswanya agar proses pembelajaran dapat berjalan secara efektif dan efisien. Pembelajaran akan dikatakan efektif apabila kegiatan tersebut dapat memberikan pengalaman baru bagi mahasiswa yang bertujuan untuk mencapai dari tujuan pembelajaran yang telah ditentukan. Teciptanya pembelajaran yang efektif dan efisien juga membutuhkan dukungan dari lingkungan belajar yang kondusif. Oleh sebab itu seorang dosen harus mampu mengelola mahasiswa, kegiatan pembelajaran, materi dan media pembelajaran yang menarik. Media yang sering digunakan bisa berupa video conference atau sharing materi dan diskusi dalam satu aplikasi.

Media pembelajaran menjadi bagian yang penting dalam masa pembelajaran daring, hal ini ditujukan untuk menarik minat belajar mahasiswa dan juga mempermudah mahasiswa dalam menyerap ilmu yang diberikan. Penggunaan media pembelajaran terus berkembang seiring perkembangan zaman dan juga teknologi. Perkembangan media pembelajaran yang semula sederhana kemudian saat ini telah berubah menjadi multimedia yang jauh lebih canggih yang juga merupakan gabungan dari dua jenis media atau lebih. Video menjadi salah satu multimedia yang banyak digunakan dalam proses pembelajaran masa kini.

Video yang ditampilkan dalam pembelajaran dapat menggunakan narasi, animasi dan rekaman-rekaman kegiatan yang menunjukkan tahapan-tahapan dari proses kerja, hal ini memiliki keterkaitan dengan apa yang dikemukakan oleh Rusman dkk, (2012:218) yang menyatakan bahwa Video merupakan serangkaian gambar gerak yang disertai oleh suara dan teks yang membentuk satu kesatuan yang dirangkai menjadi sebuah alur yang disimpan dengan proses penyimpanan pada media disk. Seiring perkembangan ilmu pengetahuan dan teknologi, maka proses pembelajaran dengan media video menjadikan dosen hanyalah sebagai fasilitator.

Universitas Sang Bumi Ruwa Jurai merupakan salah satu Perguruan Tinggi yang menerapkan pembelajaran daring dalam masa new normal ini, namun pada proses pelaksanaannya ada beberapa kendala yang menghambat pembelajaran daring. Setelah berjalannya proses pembelajaran daring, peneliti mengidentifikasi permasalahan yang muncul dalam pembelajaran daring diantarnya adalah mahasiswa merasa kesulitan menyerap materi yang disampaikan oleh dosennya karena beberapa dosen hanya membagikan materi yang dalam bentuk pdf atau powerpoint. Materi yang diberikan kurang manarik sehingga mahasiswa merasa malas dan bosan untuk mempelajarinya dan didukung juga oleh tidak adanya penjelasan langsung dari dosen pengampu yang menjabarkan materi. Ketika dosen memberi materi hanya berupa teks yang berisi materi maka mahasiswa merasa bahwa pembelajaran daring sangatlah membosankan. 
Media pembelajaran yang ditampilkan selama ini juga belum dapat menarik minat mahasiswa untuk dapat belajar secara aktif dan komprehensif. Keterbatasan penggunaan media pembelajaran yang digunakan hanaya sebatas memberikan modul dan power point saja menjadikan mahasiswa kurang aktif, hal ini dikarenakan modul dan power point kurang menarik untuk dipelajari. Hanya beberapa mahasiswa saja yang antusias untuk mempelajari dan dapat memahami materi yang diberikan dosennya dalam bentuk modul dan power point. Kurangnya perhatian dan konsentrasi dari mahasiswa dalam mengikuti proses pembelajaran juga menjadi kendala dalam mencapai tujuan pembelajaran yang telah ditentukan.

Berdasarkan latar belakang masalah diatas, peneliti dapat membuat rumusan masalah yaitu bagaimana pengembangan media pembelajaran video pada mata kuliah bahassa inggris di era new normal dan bagaimana kelayakan media pembelajaran video pada mata kuliah bahassa inggris di era new normal. Setelah menetapkan rumusan masalah maka tujuan penelitian ini adalah untuk mengembangkan media pembelajaran video pada mata kuliah bahassa inggris di era new normal dan untuk mengetahui kelayakan media pembelajaran video pada mata kuliah bahassa inggris di era new normal.

Ada beberapa penelitian yang telah dilakukan oleh peneliti sebelumya mengenai media pembelajaran dengan menggunakan video diantaranya Penelitian yang dilakukan oleh Agustina (2009) dengan judul "Pengembangan Video Pembelajaran Pengolahan Cake dengan Substitusi Labu Kuning Pada Mata Pelajaran Pengolahan Kue dan Roti Di SMK N 2 Godean Yogyakarta”, Penelitian Widiastuti (2011) yang berjudul "Pengembangan Video Pembelajaran Pewarnaan Serat Daun Suji Dengan Zat Warna Alam Untuk Siswa SMK N 5 Yogyakarta" dan Penelitian Betri Cahyani (2006) yang berjudul " Pengaruh Video Compact Disc (VCD) Terhadap Pengusaan Materi Topik Tahapan Pelaksanaan Pelayanaan Restoran Pada Siswa Kelas 1 SMK N 1 Sewon Bantul Yogyakarta".

Menurut Mulyatiningsih (2011) penelitian dan pengembangan (research and development) bertujuan untuk menghasilkan produk baru melalui proses pengembangan, sedangkan menurut Sukmadinata (2009 : 164) mengatakan bahwa penelitian dan pengembangan Research and Development (R\&D) adalah suatu proses atau langkahlangkah untuk mengembangkan suatu produk baru atau menyempurnakan produk yang telah ada berbentuk benda atau perangkat keras (hardware), seperti buku, modul, alat bantu pembelajaran di kelas atau laboraturium, ataupun model-model pendidikan, pembelajaran, pelatihan, bimbingan, evaluasi, manajemen, dll. Pengembangan atau dalam bahasa inggrisnya Research and Development adalah metode penelitian yang digunakan untuk menghasilkan produk tertentu, dan menguji keefektifan produk tersebut.

Menurut Ibrahim dan Syaodih (1996), media pembelajaran adalah segala sesuatu yang dapat digunakan untuk menyampaikan pesan atau isi pelajaran, merangsang pikiran, perasaan, perhatian, dan kemampuan siswa sehingga dapat mendorong proses belajar mengajar. Sedangkan menurut Sudjana dan Rivai (2010:1), media pengajaran ada dalam komponen metodologi, sebagai salah satu lingkungan belajar yang dianut oleh guru. Agar seorang guru dalam menggunakan media pendidikan dapat efektif, setiap guru harus dapat memiliki pengetahuan dan pemahaman yang cukup tentang media pendidikan atau pengajaran. Guru dituntut untuk harus selalu kreatif dan memahami kebutuhan mengajar 
seiring dengan majunya teknologi. Berikut ini akan disajikan mengenai pengetahuan dan pemahaman tentang media pembelajaran.

Menurut Kurniawan (2013:9) pemakaian media pembelajaran dalam proses pembelajaran juga dapat meningkatkan pemahaman konsep dan dapat meningkatkan kreativitas siswa, membuat siswa lebih tertarik untuk memperhatikan penjelasan dari guru dan juga dapat membantu siswa untuk menerima informasi dengan selutuh panca indra. Manfaat dari media pembelajaran secara umum dapat disimpulkn sebagai berikut: a) memperjelas pesan agar tidak terlalu verbalitas, b) mengatasi keterbatasab ruang, waktu dan tenaga, c) Menumbuhkan gairah belajar, interaksi lebih langsung antara murid dengan sumber belajar, d) Memungkinkan anak belajar mandiri sesuai dengan bakat dan kemampuan visual auditorium dan konektetisnya, e) Memberi stimulus yang sama untuk dapat merasakan pengalaman dan menimbulkan persepsi yang sama. Seorang dosen dapat mengembangakan sendiri media pembelajaran bagi kelas mereka sesuai dengan kebutuhan dan karakteristik para mahasiswanya. Pengembangan media ini dapat dilakukan dengan manganilisa kebutuhan kelas dan juga menyesuaikan dengan mata kuliah yang akan disampaikan.

Menurut Riyana (2007) media video pembelajaran adalah media yang menyajikan audio dan visual yang berisi pesan-pesan pembelajaran baik yang berisi konsep, prinsip, prosedur, teori aplikasi pengetahuan untuk membantu pemahaman terhadap suatu materi pembelajaran. Video merupakan bahan pembelajaran tampak dengar (audio visual) yang dapat digunakan untuk menyampaikan pesan-pesan/materi pelajaran. Dikatakan tampak dengar kerena unsur dengar (audio) dan unsur visual/video (tampak) dapat disajikan serentak. Video yaitu bahan pembelajaran yang dikemas melalaui pita video dan dapat dilihat melalui video/VCD player yang dihubungkan ke monitor televisi (Sungkono 2003:65).

Media video pembelajaran dapat digolongkan kedalam jenis media audio visual aids (AVA) atau media yang dapat dilihat dan didengar. Biasanya media ini disimpan dalam bentuk piringan atau pita. Media VCD adalah media dengan sistem penyimpanan dan perekam video dimana signal audio visual direkam pada disk plastic bukan pada pita magnetic (Arsyad 2004:36). Keuntungan menggunakan media video menurut Daryanto (2010:90) antara lain: ukuran tampilan video sangat fleksibel dan dapat diatur sesuai kebutuhan, video merupakan bahan ajar non cetak yang kaya informasi dan lugas karena dapat sampai kehadapan siswa secara langsung, dan video menambah suatu dimensi baru terhadap pembelajaran.

\section{METODE PENELITIAN}

Penelitian ini dilaksanakan di Universitas Sang Bumi Ruwa Jurai pada semester satu yang beralamat di Jl. Imam Bonjol, No. 468, Langkapura, Bandar Lampung. Pelaksanaan Penelitian Pengambangan dilakukan pada Bulan Juli-November 2020. Metode Penelitian merupakan cara yang digunakan dalam sebuah penelitian untuk mencapai tujuan yang telah dirumuskan. Penelitian ini merupakan jenis penelitian dan pengembangan yang juga disebur Research and Development (R\&D). Makna dari penelitian dan pengembangan berfokus pada proses serta menghasilkan objek pada yang dapat dilihat dan diraba sebagai hasil akhirnya. 
Metode Penelitian dan Pengembangan adalah metode penelitian yang digunakan untuk menghasilkan produk tertentu dan menguji keefektifan produk tersebut (Sugiyono, 2009: 407). Metode penelitian pengembangan yang digunakan dalam penelitian ini berfungsi untuk menghasilkan dan mengembangkan suatu produk pembelajaran pada mata kuliah Bahasa Inggris. Media pembelajaran yang berupa video didesain sedemikian rupa agar menarik dan dapat dengan mudah dipahami secara visual, dengar dan praktikan. Video yang akan dihasilkan menyajikan materi secara audio, visual dan juga berisi evaluasi berupa latihan-latihan soal. Penelitian ini bertujuan untuk mengembangkan media pembelajaran berupa video pada mata kuliah bahasa Inggris dengan materi Simple Present Tense. Prosedur penelitian ini mengadaptasi model pengembangan ADDIE. Model pengembangan ini terdiri dari lima tahapan yaitu analisis (analysis), desain (design), pengembangan (development), implementasi (implementation) dan evaluasi (evaluation) (Sugiyono, 2015:200).

Subjek yang diteliti dalam penelitian pengembangan ini adalah Mahasiswa Semester Ganjil 2020/2021 pada Universitas Sang Bumi Ruwa Jurai, sedangkan yang menjadi objek dalam penelitian ini adalah media pembelajaran video dengan materi Simple Present Tense. Teknik pengumpulan data yang digunakan dalam penelitian ini adalah dengan menggunakan Angket. Angket merupakan teknik pengumpulan data yang dilakukan dengan cara menyiapkan seperangkat pernyataan atau pertanyaam tertulis yang diberikan kepada responden untuk dijawab. Pada penelitian ini penggunaan angket bertujuan untuk mengetahui kevalidan dan kelayakan media pembelajaran yang dikembangkan.

Angket yang digunakan dalam penelitian ini adalah angket validasi dan angket untuk mengetahui respon. Angket validasi digunakan memperoleh penilaian kevalidan dari tim ahli mengenai media pembelajaran yang telah dibuat. Sasaran angket validasi media pembelajaran ini ditujukan pada satu ahli materi, satu peer review, satu ahli media dan juga diberikan pada para mahasiswa. Subjek uji coba ahli ini memiliki kriteria secara akademis, yaitu dosen ahli materi merupakan dosen mata kuliah pembelajaran dan dosen ahli media merupakan dosen media dan sumber belajar. Hasil dari validasi produk oleh tim ahli selanjutnya digunakan sebagai acuan untuk melakukan perbaikan agar menghasilkan media pembelajaran yang lebih baik. Angket respon mahasiswa digunakan untuk mengetahui kelayakan media yang dikembangkan.

Instrumen merupakan alat ukur dan pedoman observasi untuk mengumpulkan data dalam penelitian. Instrumen yang digunakan dalam penelitian ini adalah angket. Angket yang disebarkan dalam penelitian ini bertujuan untuk mendapatkan data kelayakan penggunaan media pembelajaran video pada mata kuliah bahasa inggris. Angket yang digunakan dalam penelitian ini adalah angket validasi dan angket respon. Angket validasi digunakan untuk menunjukkan adanya tingkat kevalidan suatu media. Penelitian ini menggunakan dua angket penilaian untuk menvalidasi media pembelajaran yakni satu angket untuk ahli materi dan satu angket untuk ahli media. Adapun aspek penilaian yang digunakan dalam angket validasi ahli materi dan media. Angket respon mahasiswa digunakan untuk memperoleh data mengenai respon mahasiswa terhadap pengoperasian atau penggunaan media. Hasil penilaian angket respon mahasiswa akan menunjukkan kepraktisan media yang digunakan. Angket yang digunakan menggunakan Skala Likert dengan lima alternatinative jawaban. 
Teknik analisis data yang digunakan untuk mengnalisis data kualitatif hasil validasi dengan teknik perhitungan rata-rata. Fungsi perhitungan untuk mengetahui peringkat nilai akhir butir yang ingin ketahui. Rumus perhitungan rata-rata adalah sebagai berikut:

Keterangan :

$$
\mathrm{P}=\frac{\sum x}{\sum x_{i}} \times 100 \%
$$

$\mathrm{P} \quad=$ Kelayakan

$\sum x=$ Jumlah jawaban penilaian

$\sum x_{i}=$ Jumlah jawaban tertinggi

Tabel 1. Kriteria Kevalidan Data Angket

\begin{tabular}{ccc}
\hline No & Range prosentase & Kriteria \\
\hline 1. & $81 \%-100 \%$ & Sangat baik/layak \\
2. & $61 \%-80 \%$ & Baik/layak \\
3. & $41 \%-60 \%$ & sedang \\
4. & $21 \%-40 \%$ & buruk \\
\hline
\end{tabular}

\section{HASIL DAN PEMBAHASAN}

Penelitian ini menghasilkan pengembangan media pembelajaran berupa video yang berisikan materi Bahasa Inggris tentang Simple Present Tense. Tujuan dari pengembangan media pembelajaran ini adalah untuk dijadikan sebagai bahan ajar yang dapat membantu mempermudah proses pembelajaran pada perkuliahan dalam jaringan. Berikut Langkah-langkah yang digunakan dalam mengambangkan media pembelajaran.

Pada tahap analisis, dilakukan proses pengamatan pada perkuliahan Bahasa Inggris di Fakultas Hukum Univerisitas Sang Bumi Ruwa Jurai. Tahap awal yang dilakukan adalah mencari tahu permasalahan yang berkaitan dengan pembelajaran dalam jaringan. Berdasarkan hasil pengamatan ditemukan bahwa siswa merasa kesulitan dalam menyerap materi yang disampaikan pada proses pembelajaran dalam jaringan, media pembelajaran yang terbatas, dan tampilan media pembelajaran yang kurang menarik sehingga mahasiswa sering kali merasa bosan. Hal ini yang mendorong munculnya ide untuk mengembangkan media pembelajaran yang dapat memperudah mahasiswa dalam mengikuti pembelajaran daring.

Analisa yang dilakukan pada tahapan ini adalah analisis kebutuhan mahasiswa dan analisis materi Bahasa Inggris yang akan disampaikan. Pada tahap analisis kebutuhan mahasiswa diperoleh hasil bahwa mahasiswa membutuhkan media pembelajaran yang dapat mempermudah mereka dalam belajar Bahasa Inggris dan tentunya dikemas dalam bentuk yang meanrik agar tidak membosankan untuk mempelajarinya. Materi yang disajikan dalam video pembelajaran adalah mengenai Simple Present Tense. Berdasarkan hasil analisis diatas maka peneliti mengembangkan media pembelajaran berupa video dengan materi Simple Present Tense menggunakan Adobe Premier Pro. Video pembelajaran tersebut digunakan untuk mengatasi permasalahan yang dihadapai dalam proses pembelajaran dalam jaringan dan untuk menarik minat mahasiswa untuk mempelajari Bahasa Inggris. 
Pada tahap kedua ini dilakukan dengan merancang video pembelajaran sesuai dengan format perancangan video pembelajaran. Video pembelajaran dirancang dengan tampilan menarik dan bahasa yang mudah dipahami serta berisi materi yang akan dipelajari. Setelah kerangka ditentukan maka dilakukan perancangan awal untuk mendapatkan cerita dalam video pembelajaran. Penyesuaian isi matero video pembelajaran disesuaikan dengan kompetensi dasar. Pengisi materi dalam video pembelajaran tersebut adalah peneliti itu sendiri. Pengambilan gambar dilakukan dilingkungan Universitas Sang Bumi Ruwa Jurai. Setelah dilakukan pengambilan gambar kemudian dilakukan proses pengeditan video dengan menggunakan Adobe Premier Pro. Dalam proses pengeditan ada banyak proses yang dilakukan seperti adanya penyesuaian antara video penjelasan dan materi yang ditampilkan. Setelah tahap pengeditan selesai maka dilanjutkan pada tahap selanjutnya yaitu tahap pengembangan yang berupa validasi media pembelajaran oleh ahli.

Pada tahap pengembangan media dilakukan berdasarkan rancangan pembuatan yang ada pada tahap design. Video yang telah selesai proses pengeditannya kemudian akan dilakukan tahap validasi. Uji kelayakan ini dilakukan oleh ahli materi, ahli media dan peer review. Setelah melakukan beberapa tahapan penelitian pengembangan selanjutnya diterapkan pada kondisi yang sebenarnya. Video pembelajaran diberikan kepada mahasiswa setelah dinyatakan layak oleh validator. Evaluasi yang dilakukan untuk mengukur kelayakan media pembelajaran, Hasil evaluasi digunakan untuk memberi umpan balik kepada pihak pengguna media pembelajaran, Revisi yang dibuat akan disesuaikan dengan hasil evaluasi berdasarkan pada kekurangan yang terdapat pada tahap pengembangan media pembelajaran.

Uji validasi dilakukan dengan cara membagikan angket kepada para responden serta mencantumkan link videonya pada angket tersebut. Tujuan dari pembagian angket kepada para responden adalah untuk dapat menjaring masukan sebagai bahan perbaikan media pembelajaran yang telah dikembangkan. Uji validasi dilakukan dengan mengisi angket berdasarkan link angket yang telah dibagikan kepada masing-masing ahli dan juga mahasiswa. Setelah adanya uji validasi darai para ahli materi, ahli media dan peer review maka dilanjutkan dengan pemberian angket kepada para mahasiswa. Data isian angket didapatkan dalam angka yang kemudian akan dimasukan dalam perhitungan yang hasilnya dijadikan sebagai bahan penialaian kelayakan.

Validasi yang dilakukan oleh ahli materi dilakukan dengan mengisi kuesioner setelah melihat media pembelajaran yang dibagikan melalui link. Validasi ini digunakan untuk menguji kelayakan materi, pengisian kesimpulan validasi materi, pengisian saran untuk perbaikan materi. Validasi materi dapat dilihat pada perhitungan dibawah ini :

$$
\begin{aligned}
& \mathrm{P}=\frac{\sum x}{\sum x_{i}} \times 100 \% \\
& \mathrm{P}=\frac{36}{40} \times 100 \% \\
& \mathrm{P}=90 \%
\end{aligned}
$$

Hasil dari uji kelayakan media pembelajaran oleh Ahli Materi dapat dilihat dalam diagram sebagai berikut : 


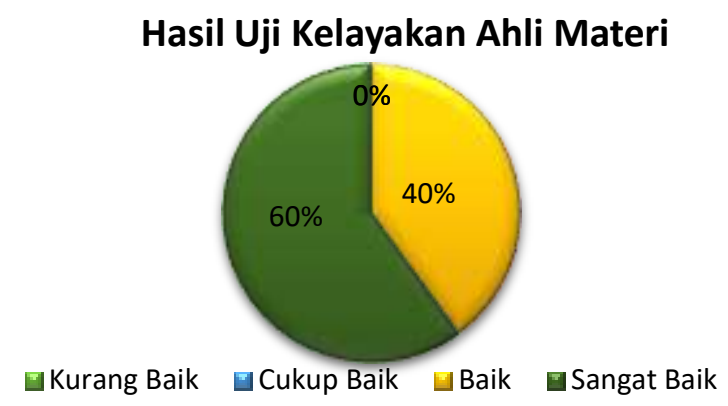

Hasil penilaian kelayakan materi pada video pembelajaran dapat dilihat dalam persentase yang ada pada diagram batang dengan penjelasan yaitu kurang baik $0 \%$, cukup baik $0 \%$, baik $40 \%$ dan sangat baik $60 \%$. Total jumlah penilaian dari validasi materi ini adalah 36 dengan peritungan rata-rata 90\%. Apabila skor rerata tersebut dikonversikan dalam hasil penilaian pada tabel validasi maka akan didapatkan hasil dengan kategori sangat layak.

Validasi oleh ahli media dilakukan dengan mengisi kuisioner yang telah dibagikan melalui link google form. Pengisian angket ini bertujuan untuk mendapatkan hasil uji kelayakan media, pengisian kesimpulan validasi media dan juga pengisian saran yang dapat digunakan sebagai bahan evaluasi dan perbaikan media pembelajaran berupa video tersebut. Valdidasi media dengan pengisian kuesioner untuk kelayakan media dapat dilihat pada perhitungan dibawah ini:

$$
\begin{aligned}
& \mathrm{P}=\frac{\sum x}{\sum x_{i}} \times 100 \% \\
& \mathrm{P}=\frac{36}{40} \times 100 \%
\end{aligned}
$$

$\mathrm{P}=90 \%$

Dari hasil uji kelayakan media video pembelajaran pada mata kuliah Bahasa Inggris oleh ahli media dapat dilihat dalam diagram sebagai berikut:

Diagram 2 Hasil Uji Kelayakan Ahli Media

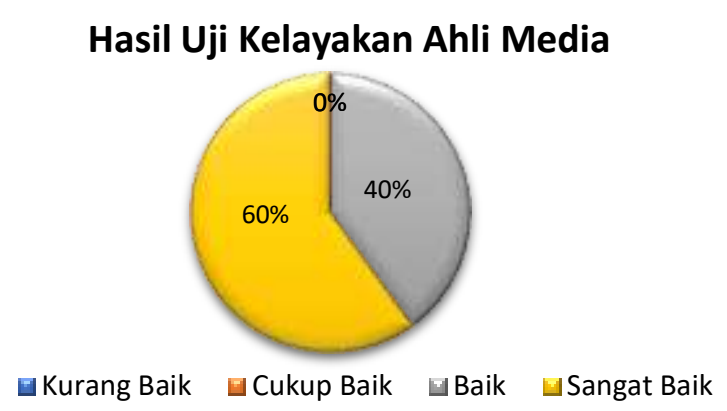

Persentasi yang diperoleh dari hasil penilaian kelayakan media pembelajaran berupa video pada mata kuliah Bahasa Inggris diperoleh hasil yaitu kurang baik 0\%, cukup baik $0 \%$, baik $40 \%$ dan sangat baik $60 \%$. Total jumlah skor penilaian dari validasi ahli media yaitu 36 dengan rerata perhitungan dalam persen yaitu $90 \%$. Hasil rerata yang didapatkan apabila dikonversikan dalam tabel konversi nilai angket validasi maka diperoleh hasil penilaian dari ahli media dalam kategori sangat layak. 
Validasi oleh peer review dilakukan dengan mengisi kuesioner berdasarkan video yang telah ditonton. Validasi ini digunakan untuk menguji kelayakan materi dalam media pembelajaran, pengisian kesimpulan validasi materi, pengisian saran untuk perbaikan materi. Validasi materi dapat dilihat pada perhitungan dibawah ini:

$$
\begin{gathered}
\mathrm{P}=\frac{\sum x}{\sum x_{i}} \times 100 \% \\
\mathrm{P}=\frac{35}{40} \times 100 \% \\
\mathrm{P}=88 \%
\end{gathered}
$$

Hasil dari uji kelayakan media pembelajaran oleh peer review dapat dilihat dalam diagram sebagai berikut :

Diagram 3 Hasil Uji Kelayakan Peer Review

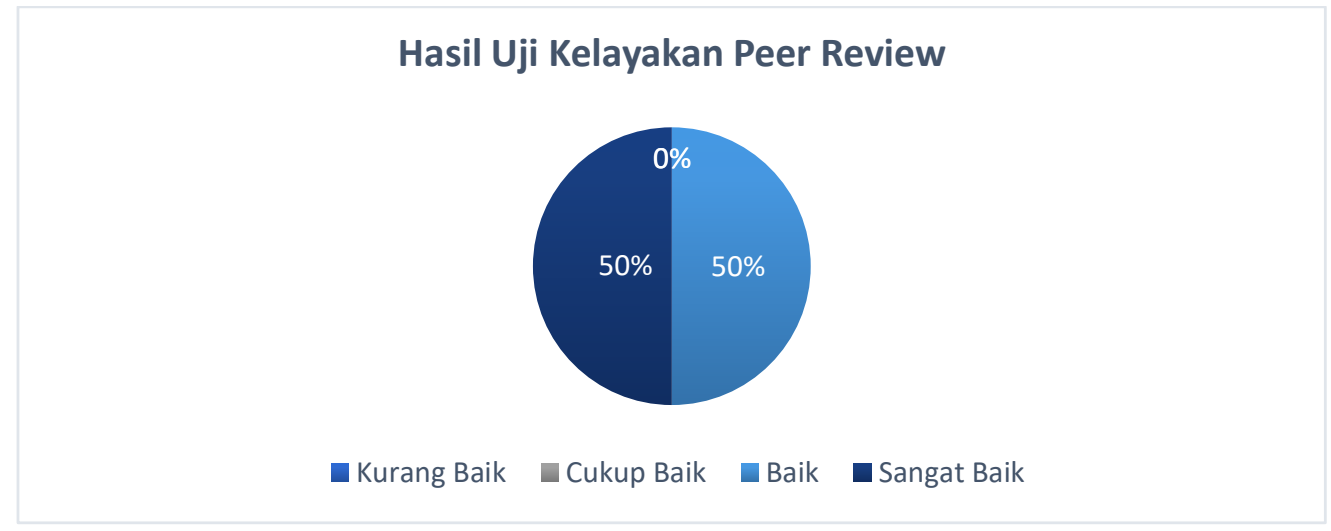

Persentase hasil dari penilaian kelayakan materi pembelajaran oleh peer review yaitu kurang baik 0\%, cukup baik 0\%, baik 50\% dan sangat baik 50\%. Total jumlah skor validasi ahli materi adalah 35 dengan rerata yang diperolah $88 \%$. Skor rerata yang telah didapatkan dari penialaian oleh peer review apabila dikonversikan dalam tabel kriteria validasi, maka dari hasil penilaian materi pada media pembelajaran ini dapat dikategorikan dalam kriteria sangat layak.

Uji coba kepada mahasiswa dilakukan setelah uji validasi oleh ahli materi, ahli media dan peer review. Uji validasi ini dilakukan kepada 39 mahasiswa pada fakultas hukum semester yang mengambil mata kuliah wajib umum yaitu Bahasa Inggris. Hasil uji validasi dapat dilihat pada perhitungan berikut ini:

$$
\begin{array}{r}
\mathrm{P}=\frac{\sum x}{\sum x_{i}} \times 100 \% \\
\mathrm{P}=\frac{1325}{1560} \times 100 \% \\
\mathrm{P}=85 \%
\end{array}
$$

Dari hasil uji validasi oleh mahasiswa di dapatkan hasil sesuai pada diagram sebagai berikut: 
Seminar Nasional Penelitian dan Pengabdian kepada Masyarakat Universitas Sang Bumi Ruwa Jurai Tahun 2020

Diagram 4 Hasil Uji Kelayakan Mahasiswa

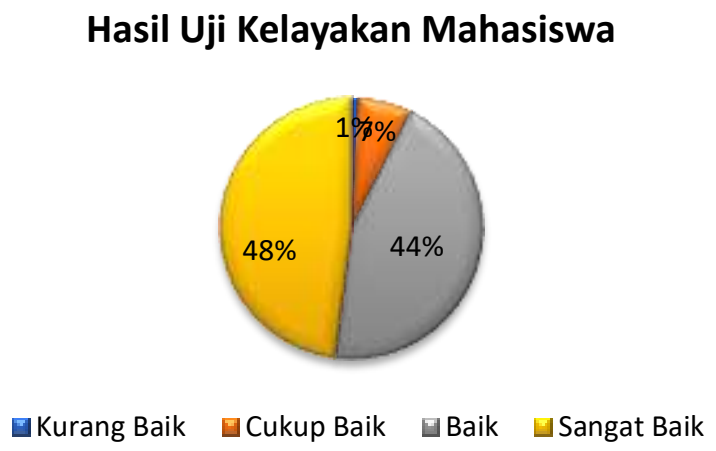

Persentase hasil dari uji validasi oleh mahasiswa didapatkan hasil yaitu kurang baik $1 \%$, cukup baik $7 \%$, baik $44 \%$ dan sangat baik $48 \%$. Total jumlah skor yang diperoleh dari penilaian oleh mahasiswa melalui angket adalah 1325. Skor rerata yang diperoleh yaitu $85 \%$. Apabila dikonversikan dalam tabel konversi uji validasi untuk mengukur kelayakan video pembelajaran tersebut maka didapatkan hasil bahwa video pembelejaran ini masuk kedalam kategori sangat layak.

Selain uji coba kelayakan media pembelajaran oleh mahasiswa, dalam penelitian ini juga dijabarkan hasil perhitungan penilaian kelayakan aspek yang ada pada kisi-kisi angket uji validasi. Hasil yang didapatkan dari perhitungan setiap aspek pada kisi-kisi angket didapatkan hasil sebagai berikut:

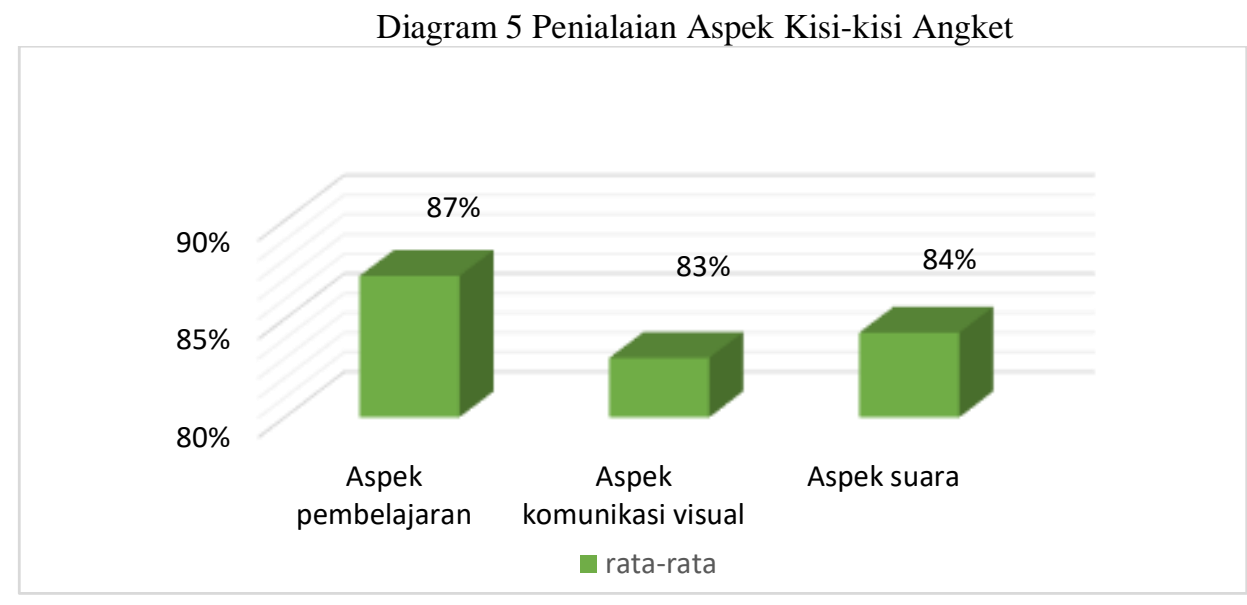

Diagram diatas merupakan hasi perhitungan data dari 39 mahasiswa dengan jumlah butir soal sebanyak 10. Berdasarkan tabel diatas dapat diartikan bahwa kelayakan video ditinjau dari masing-masing aspek dapat dijabarkan yaitu pada aspek pembelajaran rata-rata yang didapatkan yaitu sebesar $87 \%$ yang masuk dalam kategori sangat layak. Pada aspek komunikasi visual didapatkan hasil rata-rata yaitu $83 \%$ yang juga dikategorikan sangat layak. Sedangkan pada aspek suara diperoleh hasil rata-rata yaitu $84 \%$ yang juga masuk dalam kategori sangat layak. Hal ini menunjukkan bahwa penilaian video pembelajaran pada masing-masing aspek telah memenuhi kriteria sangat layak untuk digunakan sebagai media pembelajaran pada proses pembelajaran dalam jaringan.

Berdasarkan hasil pengamatan pada tahap analisis kelayakan pengembangan media pembelajaran ditemukan beberapa hal yang menjadi kendala dalam proses 
pembelajaran secara daring. Masalah yang ditemukan muncul dari beberapa faktor yaitu media pembelajaran yang kurang menarik, menurunnya minat belajar mahasiswa dan juga keterbatasan media pembelajaran yang ditampilkan oleh dosen. Oleh karena itu muncul ide mengembangkan media pembelajaran yang mampu memudahkan mahasiswa dan juga meningkatkan minat belajar mereka. Analisis yang dilakukan pada tahap ini yaitu analisis kebutuhan siswa dalam belajar dan analisis materi pada mata kuliah wajib umum Bahasa Inggris.

Pemilihan video pembelajaran sebagai pendukung media pembelajaran yang dikembangkan karena dapat memudahkan mahasiswa untuk belajar dengan tampilan yang menarik sehingga mahasiswa menyukai pelajaran Bahasa Inggris. Video pembelajaran dapat digunakan sebagai alat bantu mengajar karena video pembelajaran merupakan media yang memiliki unsur suara dan gerak. Setelah tahap analisis, tahap selanjutnya adalah tahap design pada tahap ini dilakukan format perencanaan video pembelajaran, Dalam skenario yang telah dirancang selanjutnya dibuatlah video berdasarkan perencanaan. Setelah selesai dirancang kemudian dilanjutkan pada tahap editing video. Setelah video selesai dibuat, Langkah selanjutnya adalah tahap development.

Pada tahap development pengembangan media pembelajaran mulai dilakukan dengan cara uji validasi oleh para ahli. Tujuannya adalah untuk memperoleh saran dan masukan guna memperbaiki video pembelajaran yang dikembangkan. Penilaian dan masukan dari para ahli dijadikan sebagai bahan acuan untuk dilakukannya revisi. Selain itu juga uji validasi digunakan sebagai penentu layak atau tidaknya video tersebut di jadikan sebagai media pembelajaran dalam jaringan. Dalam proses pengembangan media pembelajaran ini telah melalui beberapa tahapan perbaikan agar terlihat menjadi lebih menarik.

Penilaian oleh para ahli dan mahasiswa dapat dijabarkan yaitu uji validasi ahli materi terhadapa media pembelajaran ini masuk dalam kategori sangat layak dengan persentase rata-rata sebesar $90 \%$. Penilaian oleh ahli media terhadap media pembelajaran ini adalah masuk dalam kategori sangat layak dengan persentase rata-rata sebesar $90 \%$ dan penilaian dari peer review mendapatkan hasil bahwa media pembelajaran ini masuk dalam kategori sangat layak dengan persentase rata-rata yaitu sebesar $88 \%$.

Pada tahap implementasi didapatkan respon dari para mahasiswa yang telah mengisi angket uji validasi. Berdasarkan angket yang telah disebarkan diperoleh hasil perhitungan persentase rata-rata seebesar $85 \%$ dengan kategori sangat layak, Setelah tahap ini tidak ada lagi revisi yang perlu dilakukan karena peserta didik telah menyatakan bahwa media pembelajaran yang dikembangkan sudah baik. Berdasarkan perhitungan masing-masing aspek pada angket mahasiswa diperoleh besaran rata-rata yaitu pada aspek pembelajaran sebesar $87 \%$ yang masuk dalam kategori sangat layak, aspek komunikasi visual didapatkan hasil rata-rata yaitu $83 \%$ yang juga dikategorikan sangat layak dan pada aspek suara diperoleh hasil rata-rata yaitu $84 \%$ yang juga masuk dalam kategori sangat layak.

\section{SIMPULAN DAN SARAN}

Berdasarkan data hasil penelitian dan pembahasan yang telah diuraikan maka dapat ditarik kesimpulan bahwa pengembangan media pembelajaran berupa video dalam 
Seminar Nasional Penelitian dan Pengabdian kepada Masyarakat Universitas Sang Bumi Ruwa Jurai Tahun 2020

penelitian ini dilakukan dengan beberapa tahapan yaitu analyze, design, development, implementation dan evaluation dan hasil dari uji validasi yang dilakukan oleh ahli materi, ahli media dan peer review untuk mengukur kelayakan media pembelajaran berupa video untuk mendukung proses pembelajaran dalam jaringan pada mata kuliah Bahasa Inggris memperoleh kategori sangat layak. Setelah medapatkan hasil uji validasi oleh para ahli dilanjutkan dengan uji validasi yang dilakukan oleh mahasiswa fakultas hukum yang mengambil mata kuliah wajib umum dengan jumlah sebanyak 39 mahasiswa di Universitas Sang Bumi Ruwa Jurai juga memperoleh kategori sangat layak. Hasil ini diperoleh dari data isian angket yang telah disebarkan kepada ahli materi, ahli media, peer review dan juga mahasiswa, kemudian hasil yang diperoleh diolah dengan rumus perhitungan sehingga mendapat hasil hasil yang telah ditampilkan pada bagian pembahasan.

\section{DAFTAR PUSTAKA}

Arsyad, Lincolin. 2004. Ekonomi Pembangunan. Edisi Keempat. Yogyakarta: STIE YKPN.

Daryanto. 2010. Media Pembelajaran. Yogyakarta: Gava Media.

Ibrahim, R dan Syaodih S, Nana. 1996. Perencanaan Pengajaran. Jakarta: Rineka Cipta.

Kurniawan. 2013 Pengaruh kompetensi pedagogik, dan kompetensi professional guru. Universitas Pendidikan Indonesia : Pustaka Belajar.

Mulyatiningsih, Endang. 2011. Metode Penelitian Terapan Bidang Pendidikan. Yogyakarta: Alfabeta

Riyana, Cheppy. 2007. Pedoman Pengembangan Media Video. Jakarta: P3AI UPI.

Sudjana, Nana dan Rivai, Ahmad. 2010. Media Pengajaran. Bandung: Sinar Baru Algensindo.

Sugiyono. 2006. Metode Penelitian Kuantitatif, Kualitatif dan R \&. D. Bandung : Alfabeta.

Sugiyono, 2009. Metode Penelitian Kuantitatif, Kualitatif dan R\&D. Bandung : Alfabeta.

Sugiyono. 2015. Metode Penelitian Pendidikan (Pendekatan Kuantitatif, Kualitatif dan R\&D). Bandung : Alfabeta.

Sungkono.2003.Pengembangan dan Pemamfaatan Bahan Ajar Modul Dalam Proses Pembelejaran. Yogyakarta : FIP UNY. 